\title{
Influence of Nitro Group Substitutes to the Stability and Energetic Properties of $\mathrm{N}$-(2,4,6-trinitrophenyl)-1H- 1,2,4-triazol-3-amine
}

\author{
Jelena Tamuliene' ${ }^{1}$, Jonas Sarlauskas ${ }^{2}$, Svajone Bekesiene ${ }^{3}$ \\ ${ }^{1}$ Institute of Theoretical Physics and Astronomy, Vilnius University, Vilnius, Lithuania \\ ${ }^{2}$ Institute of Biochemistry, Vilnius University, Vilnius, Lithuania \\ ${ }^{3}$ The General Jonas Žemaitis Miltitary Academy of Lithuania, Vilnius, Lithuania \\ Email: Jelena.Tamuliene@tfai.vu.lt, jonas.sarlauskas@gmail.com, Svajone.Bekesiene@mil.lt
}

How to cite this paper: Tamuliene, J., Sarlauskas, J. and Bekesiene, S. (2017) Influence of Nitro Group Substitutes to the Stability and Energetic Properties of N(2,4,6-trinitrophenyl)-1H-1,2,4-triazol-3-amine. American Journal of Analytical Chemistry, 8, 125-141.

https://doi.org/10.4236/ajac.2017.82010

Received: August 25, 2016

Accepted: February 1, 2017

Published: February 4, 2017

Copyright $\odot 2017$ by authors and Scientific Research Publishing Inc. This work is licensed under the Creative Commons Attribution International License (CC BY 4.0).

http://creativecommons.org/licenses/by/4.0/

\begin{abstract}
In the paper, we aim to show $\mathrm{N}$-(2,4,6-trinitrophenyl)- $1 H$-1,2,4-triazol-3-amine (HM-I) as explosive material that satisfies requirements of sensitivity and hydrolytically stability. The influence of nitro group substitutions on the thermal and chemical stability as well as the explosive performance of HM-I is also investigated. We found that nitro group substitution to the triazole ring of HM-I can significantly improve the properties of this new material. Only $-\mathrm{NH}_{2}$ substitution position (but not their number) in the core molecule is appropriate to increase the stability and improve explosive performances of HM-I.
\end{abstract}

\section{Keywords}

Explosive Materials, Quantum Chemistry Calculations, Detonation Velocity, Oxygen Balance

\section{Introduction}

Recently, the research has been carried out into the synthesis of new energetic materials aiming to couple high density with high energy. The detonation pressure approaching kilo bars (kbar), a specific impulse and/or enhanced stability, and insensitivity to such stimuli as impact, friction, and electrostatic discharge should also be considered [1]. Additionally, energetic materials could not be quite sensitive and hydrolytically unstable. Hence, the research is in progress worldwide searching for explosives with the combination of properties such as 
safety, reliability, stability, cost-efficiency and eco-friendliness. For the synthesis of thermally stable explosives, nitro compounds have received special attention because of their ability to withstand high temperatures and the low pressures encountered in space environments [2]. Currently, general approaches influencing the thermal stability of explosive molecules are very well known [3] [4]. These approaches are the following:

1) Introduction of amino groups;

2) Condensation with a triazole ring;

3) Salt formation;

4) Introduction of conjugation.

Many studies are performed to better understand the effect of the introduction of amino groups to various compounds, e.g. 1,3,5-trinitrobenzene, 1,3diamino-2,4,6-trinitrobenzene and etc. [5] [6] [7]. Based on these studies, it was concluded that the introduction of an amino $\left(-\mathrm{NH}_{2}\right)$ group (in the ortho position) into a benzene ring already having a nitro $\left(-\mathrm{NO}_{2}\right)$ group enhanced the thermal stability of explosives. On the other hand, the new explosives containing amino groups as well as conjugation were synthesized and investigated [8] [9] [10]. Some of these new materials have the distinction of being the most thermally stable explosive reported so far in comparison to well-known thermally stable explosives.

Referring to the above studies, we modeled N-(2,4,6-trinitrophenyl)- $1 H-1,2,4$ triazol-3-amine molecule and performed theoretical investigations of it aiming to clear the influence of the nitro group and its position to both the stability, optical and hazardous properties. It must be emphasized that our general aim was to design and synthesize new energetic materials.

\section{Methods of Investigations}

\subsection{Synthesis and Experiment}

The reagents used in the study were provided by "Sigma-Aldrich, Fluka and Merck". Melting temperature of the materials under study was measured by MELT-TEMP apparatus. The reaction steps and the final materials homogeneity were controlled by the thin-layer chromatography (PSL) method and silica gel on aluminum base plate (Merck).

The IR spectra were measured on $\mathrm{KBr}$ matrix by Perkin-Elmer spectrophotometer (FT-IR Spectrum BX II).

An LC-MS investigation was performed by Agilent technologies 6246 apparatus. The general synthesis scheme is presented in Figure 1.

\subsection{Quantum Chemical Investigations}

The structure of the molecules and their fragments under study were investigated by the density functional approach (DFT). We applied Becke's three-parameter hybrid functional applying the non-local correlation provided by Lee, Yang, and Parr (B3LYP) [11], a representative standard DFT method [12]. The cc-pVTZ basis set was also applied [13]. The approach was chosen taking into account 
(a)

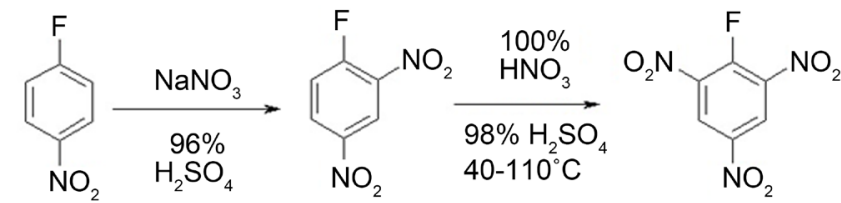

(b)
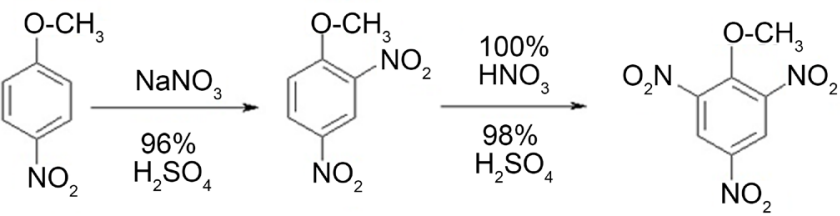

(c)<smiles>O=[N+]([O-])c1cc([N+](=O)[O-])c(F)c([N+](=O)[O-])c1</smiles><smiles>CCN(C)CCN</smiles><smiles>C[N+](C)=O</smiles>
$-5-40^{\circ} \mathrm{C}$ (-HF)<smiles>O=[N+]([O-])c1cc([N+](=O)[O-])c(Nc2nc[nH]n2)c([N+](=O)[O-])c1</smiles>

(d)<smiles>COc1c([N+](=O)[O-])cc([N+](=O)[O-])cc1[N+](=O)[O-]</smiles>

(HM-1)

Figure 1. The general synthesis scheme of $\mathrm{N}$-(2,4,6-trinitrophenyl)-1 $H$-1,2,4-triazol-3-amine (HM-1) starting from 4-fluoronitrobenzene or 4-nitroanisole.

sufficient accuracy and comparably less computing time.

To obtain the most probable structure of the molecules, the Berny optimization was performed without any symmetry constraint of several different initial geometrical structures of the molecules with the same chemical compositions. The method we used enabled us to find the most stable geometrical structure. We also computed force constants and the resulting vibrational frequencies to be sure that equilibrium point was obtained.

To describe energetic properties of the compounds investigated, the detonation velocity and oxygen balance were calculated.

The detonation velocity was calculated as follows [14]:

$$
\begin{aligned}
& D 21=-393.6877-0.2454(N E / M)-114.0793(E / M) \\
& D 22=-372.4122-1.3198(N E / M)-106.8382(E / M)
\end{aligned}
$$

where $N$ is a number of the $-\mathrm{NO}_{2}$ groups in the molecule. $E$ is total energy of a molecule, a. u., and $M$ is molar mass, $\mathrm{g} / \mathrm{mol}$. The regressed equations enabled us to get some fairly accurate ideas about detonation velocity values of explosives to compare their properties.

The oxygen balance was determined by using the following equation:

$$
O B=\frac{-16}{M}\left(2 x+\frac{y}{2}-z\right) \times 100
$$


where $M$ is molar mass, $x$-a number of $\mathrm{C}$ atoms, $y$-a number of $\mathrm{H}$ atoms, $z-\mathrm{a}$ number of $\mathrm{O}$ atoms [15]. Additionally, the toxicity and reactivity of the compounds investigated were obtained.

The transition states of the molecule under investigations were also obtained applying the Berny optimization procedure of the several different initial geometrical structures. The structures possessing the highest energy were selected for future investigations.

The IR spectra were obtained by using B3LYP/cc-pVTZ approach. The Gaussian program packages were applied [16].

\section{Results of the Investigations}

\subsection{Geometric Structures}

The views of the core molecule investigated are presented in Figure 2, the meaning of R1, R2 and R3 is presented in Table 1. Substitutions R1, R2 and R3 are $-\mathrm{H}$ or $-\mathrm{NO}_{2}$. Here, the substitution $-\mathrm{NO}_{2}$ is introduced as 'the additional $\mathrm{NO}_{2}$ (nitro) group' in order to separate it from other groups in the core molecule. The largest number of the additional nitro groups attached to the core molecule is two and their placement is different (Figure 2, Table 1). Hence, the molecules under the study are different due to different number of the nitro groups and their positions in the core molecules. We indicated the molecules investigated as HM-I - HM-VI to simplify discussion.

To observe the difference in the geometric structures of the molecules under study, the analysis of the bond length, angles and dihedral angles were performed. Generally, the bond length and angles of the core molecule

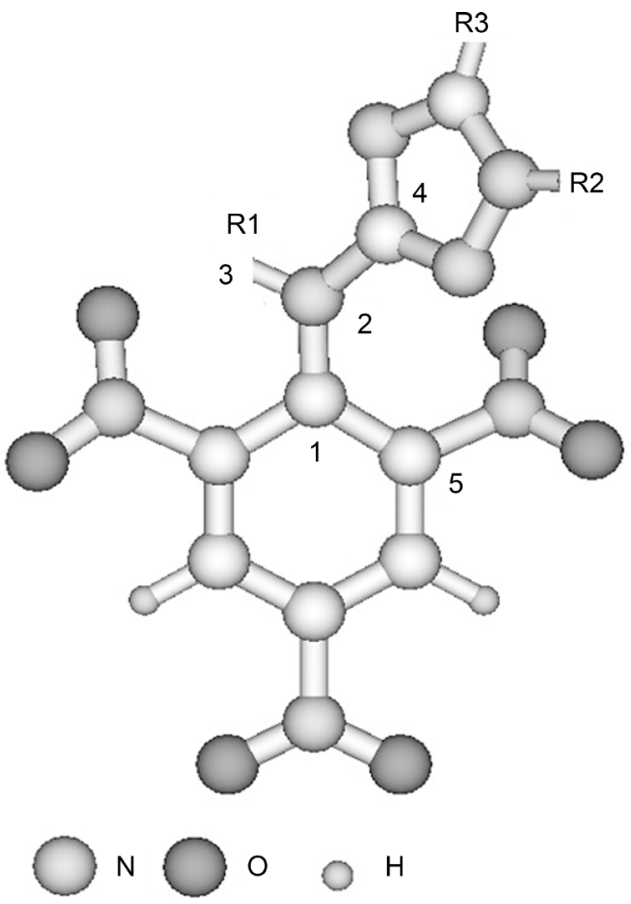

Figure 2. View of the core molecule investigated. The meaning of R1, R2 and R3 is presented in Table 2. 
Table 1. Substitutions of R1, R2 and R3 for the investigated molecules.

\begin{tabular}{cccc}
\hline Name of the molecules under study & $\mathrm{R} 1$ & $\mathrm{R} 2$ & $\mathrm{R} 3$ \\
\hline HM-I & $-\mathrm{H}$ & $-\mathrm{H}$ & $-\mathrm{H}$ \\
HM-II & $-\mathrm{NO}_{2}$ & $-\mathrm{H}$ & $-\mathrm{H}$ \\
HM-III & $-\mathrm{NO}_{2}$ & $-\mathrm{NO}_{2}$ & $-\mathrm{H}$ \\
HM-IV & $-\mathrm{NO}_{2}$ & $-\mathrm{H}$ & $-\mathrm{NO}_{2}$ \\
HM-V & $-\mathrm{H}$ & $-\mathrm{H}$ & $-\mathrm{NO}_{2}$ \\
HM-VI & $-\mathrm{H}$ & $-\mathrm{NO}_{2}$ & $-\mathrm{H}$ \\
\hline
\end{tabular}

(HM-I) do not change significantly due to the additional nitro groups. However, the dihedral angles between planes that form $(1,2,3),(5,1,2),(5,1,2)$ and $(1,2$, 4) atoms (Figure 1) are this nitro group depended (Table 2).

Clearly the above dihedral angles are significantly different when an additional nitro group is in $-\mathrm{R} 1$ or/and $-\mathrm{R} 2$ position(s). The positions are rather close to the $-\mathrm{NO}_{2}$ group of the core molecule (Figure 2). The difference between the geometrical structure of HM-I and HM-V, where the additional nitro group is in -R3 position, is insignificant (Figure 1). In this case, the additional nitro group is rather far from other nitro groups consisting of the molecules under investigations. It is obvious that the geometric structure of the molecules investigated is depended on the position of the additional group in the core molecule, i.e. depended on how far this group is from other nitro groups.

\subsection{Thermal and Chemical Stability}

To compare the stability of the derivatives investigated, the binding energy per atom is calculated and presented in Table 4. It is evident, that the stability of the molecule HM-I, where R1, R2 and R3 are $\mathrm{H}$ atoms, is the lowest in comparison to that of other investigated compounds. However, the thermogravimetric analysis of HM -I was also performed to evaluate the thermal stability of this material. In the temperature range of $25^{\circ} \mathrm{C}-320^{\circ} \mathrm{C}$ there was no observed mass change (Figure 3). That indicates that HM-I species are thermally stable, i.e. beyond $\sim 320^{\circ} \mathrm{C}$ temperature the material will begin to degrade.

It is evident that the stability of the other molecules should be higher in comparison to that of HM-I. However, we may not state that the stability of these molecules investigated increases when one of the above substitutions is $-\mathrm{NO}_{2}$, because the binding energy per atom of molecule HM-II is only $0.013 \mathrm{eV}$, i.e. less than $\mathrm{kT} \sim$ $0.02 \mathrm{eV}$, and there is no possibility to recognize which of the above-mentioned molecules HM-I or HM-II is more stable (Table 3). Moreover, the comparison of the binding energy per atom of molecule HM-II and HM-VI (which are different because of the additional nitro group attached to different $\mathrm{N}$ atoms (Figure 2, Table 3), allows us to predict that even the placement of the additional $-\mathrm{NO}_{2}$ group insignificantly influences the stability of $\mathrm{N}$-(2,4,6-trinitrophenyl)- $1 \mathrm{H}-1,2,4$-triazol3 -amine taking into account that in both cases of $\mathrm{N}^{-\mathrm{NO}_{2}}$ similar additional chemical bonds are formed. 
Table 2. The main difference of the geometric structure of HM-I - HM-VI.

\begin{tabular}{ccc}
\hline \multirow{2}{*}{ Name of the molecule under study } & \multicolumn{2}{c}{ Dihedral angles } \\
\cline { 2 - 3 } & $(1,2,3$,$) and (5,1,2)$ & $(5,1,2)$ and $(1,2,4)$ \\
\hline HM-I & 165.582 & 167.792 \\
HM-II & 127.806 & 132.059 \\
HM-III & 123.993 & 141.587 \\
HM-IV & 125.656 & 136.341 \\
HM-V & 164.336 & 168.827 \\
HM-VI & 163.376 & 171.358 \\
\hline
\end{tabular}

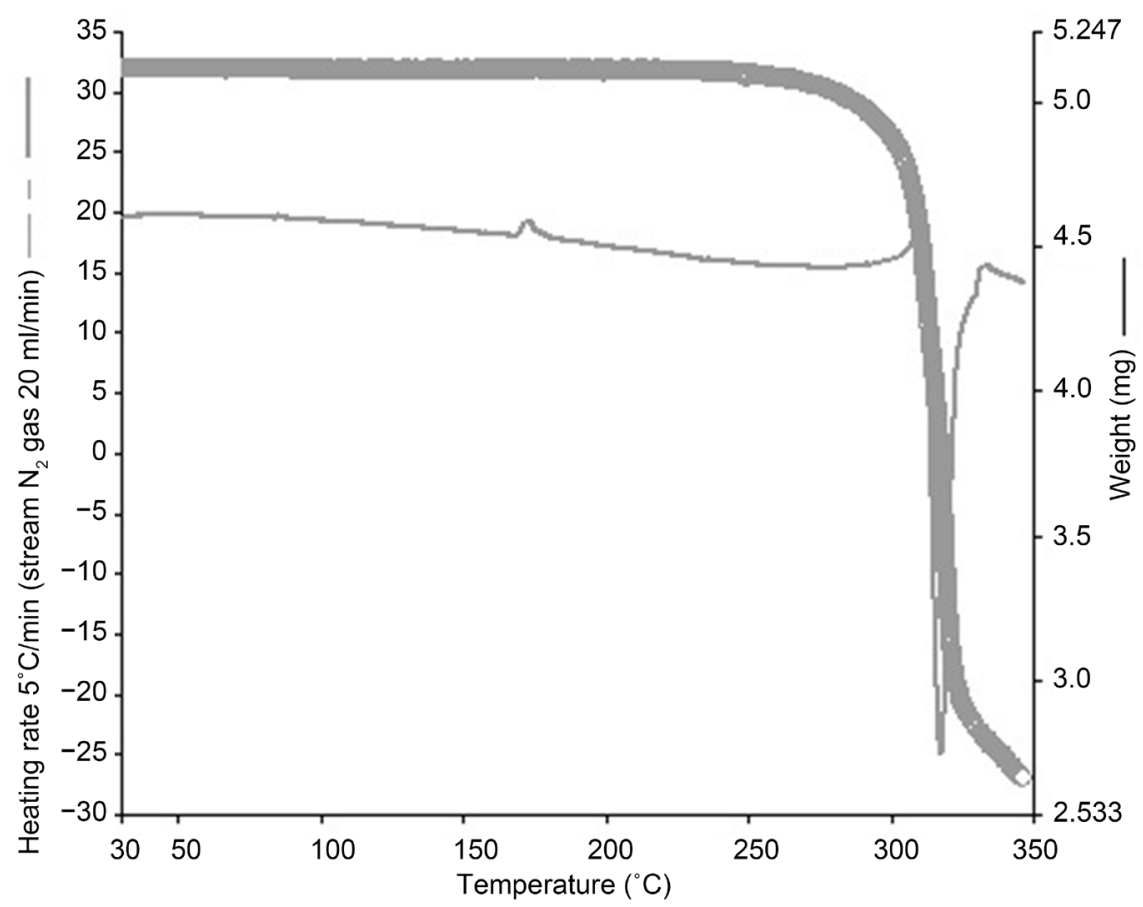

Figure 3. Results of thermogravimetric analysis of the HM-I material. Heating rate $5^{\circ} \mathrm{C} / \mathrm{min}$ (stream $\mathrm{N}_{2}$ gas $20 \mathrm{ml} / \mathrm{min}$ ).

Table 3. Binding energy per atom of the molecules investigated.

\begin{tabular}{ccc}
\hline $\begin{array}{c}\text { Name of the molecules } \\
\text { under study }\end{array}$ & $\begin{array}{c}\text { Binding energy per } \\
\text { atom, eV }\end{array}$ & $\begin{array}{c}\text { Binding energy per atom in respect the } \\
\text { stablest molecule, eV }\end{array}$ \\
\hline HM-I & 6.376 & 0.062 \\
HM-II & 6.389 & 0.048 \\
HM-III & 6.412 & 0.025 \\
HM-IV & 6.438 & 0 \\
HM-V & 6.430 & 0.008 \\
HM-VI & 6.403 & 0.035 \\
\hline
\end{tabular}

Molecules HM-V and HM-VI also have one additional $-\mathrm{NO}_{2}$ group that is attached to the $\mathrm{C}$ and $\mathrm{N}$ atoms of the triazole ring, respectively. Referring to the obtained results of the binding energy per atoms, it is evident that the stability of molecule HM-V is greater than that of HM-IV. Recall that the stability of molecule HM-II and HM-VI, when only the $\mathrm{N}-\mathrm{NO}_{2}$ bond appeared, is not different. 
These observations allow us to conclude, that the stability of the molecules investigated could increase because of the presence of the additional $-\mathrm{C}-\mathrm{NO}_{2}$ bond. A similar phenomenon is obtained in the case of molecules HM-III and HM-IV. These molecules possess the two additional $-\mathrm{NO}_{2}$ groups, and they are different due to the additional nitro group position in the triazole ring. In the case of $\mathrm{HM}-\mathrm{III}$, the $\mathrm{N}-\mathrm{NO}_{2}$ bond is formed, while C-NO 2 takes place in molecule HM-IV. Hence, the stability of $\mathrm{N}$-(2,4,6-trinitrophenyl)-1 $H$-1,2,4-triazol-3-amine could increase when the additional nitro group is attached to $\mathrm{C}$ atom. It is interesting that the number of the additional nitro groups does not have an influence on the stability of the investigated molecule: the binding energy per atom of molecule HM-IV and molecule HM-V is similar, although two and one additional nitro groups take place in these molecules respectively and one of them is attached to the $\mathrm{C}$ atom of the triazole ring.

To evaluate the chemical stability of the molecules under study, the HOMO, LUMO and the HOMO-LUMO gap are analyzed and presented in Table 4.

It is known that larger HOMO-LUMO gap indicates larger chemical stability of compounds. Hence, the sequence of the chemical stability of the molecules is as follows: HM-IV > HM-III > HM-II > HM-V > HM-VI > HM-I, i.e. HM-IV is chemically the most stable, while the chemical stability of the HM-I is the lowest. It must be emphasized, that the molecules consist of the two additional nitro groups are chemically more stable than other investigated molecules. On the other hand, the chemical stability of the HM-IV and HM-III also differs because one of the two additional nitro groups is joined with $\mathrm{C}$, but not with $\mathrm{N}$ atom. Referring to the results, we may predict that an additional nitro group and its position could increase chemical stability of HM-I significantly.

\subsection{Activation Energy}

To evaluate which of the molecules under study would be better to use as hazardous material, we calculated the activation energy - the minimum energy necessary to input to a system to cause a chemical reaction. The activation energy $E_{\text {ac }}$ is evaluated as follows:

$$
E_{a c}=\left|E_{g r}\right|-\left|E_{t r}\right|
$$

where $E_{\mathrm{gr}}$ is the total energy of the molecule at its equilibrium point, $E_{\mathrm{tr}}$ is that in the transition state. The activation energy obtained is presented in Table 5.

Table 4. Highest-lying occupied (HOMO), the lowest-lying unoccupied (LUMO) molecular orbitals and the gap between them.

\begin{tabular}{cccc}
\hline Name & HOMO, a.u & LUMO, a.u & HOMO-LUMO gap, eV \\
\hline HM-I & -0.263 & -0.130 & 3.624 \\
HM-II & -0.292 & -0.143 & 4.056 \\
HM-III & -0.307 & -0.153 & 4.207 \\
HM-IV & -0.310 & -0.154 & 4.257 \\
HM-V & -0.282 & -0.142 & 3.806 \\
HM-VI & -0.281 & -0.142 & 3.782 \\
\hline
\end{tabular}


Table 5. The activation energy obtained $\left(\Delta E_{\mathrm{ac}}\right)$ and that with respect to the smallest value of the activation energies.

\begin{tabular}{ccc}
\hline Name & $E_{\mathrm{ac}}, \mathrm{eV}$ & $\Delta E_{\mathrm{ac}}, \mathrm{eV}$ \\
\hline HM-I & 0.276 & 0.047 \\
HM-II & 0.615 & 0.387 \\
HM-III & 0.645 & 0.417 \\
HM-IV & 0.228 & 0 \\
HM-V & 0.398 & 0.170 \\
HM-VI & 0.366 & 0.138 \\
\hline
\end{tabular}

The results of the analysis of the activation energy exhibit, that the smallest energy must be input to the HM-IV to cause a chemical reaction. It is worth mentioning that the chemical stability of the molecule is the highest with respect to the other molecules under study. On the other hand, the activation energy of the molecules under study consisting of only one of the additional nitro groups is higher than that of HM-I. Hence, we may predict that the number of the additional nitro group have influences the amount of energy to be input to cause a chemical reaction.

\subsection{Detonation Velocity}

There are two well-known and widely used indicators of the performance of the hazardous materials. These indicators are the detonation velocity and pressure. The detonation velocity, an indicator of strength, is calculated using Equation (1) and Equation (2). The results are presented in Table 6. The detonation velocity as an important property to be taken into consider when rating an explosive. The detonation velocities for high explosives range from $3300 \mathrm{fps}$ to 29900 fps $(1.01 \mathrm{~km} / \mathrm{s}$ to $9.11 \mathrm{~km} / \mathrm{s})$. Hence, the results obtained indicate the molecules under investigations are highly explosive.

We would like to remind that the detonation velocity is calculated applying the regressed equations received on the basis of the quantum mechanical calculations [17]. Hence, it is not evident how precisely the above equations describe the molecules under investigation despite the fact that the Equation (1) and Equation (2) have been obtained on the basis of the research of the widely used compounds such as nitramines, aliphatic and aromatic-nitro. It implies, that the results obtained required an experimental confirmation. However, the detonation velocity of the molecules under investigation is obtained by using the same approach, i.e. the statistic errors of the investigations of the individual molecule could not be significantly different. It allows us to compare performance of the compounds investigated despite the model used and to rate the molecules under study. Referring to the results obtained the order of the strength of the materials is the following: HM-IV = HM-III $>\mathrm{HM}-\mathrm{V}=\mathrm{HM}-\mathrm{VI}=\mathrm{HM}-\mathrm{II}>\mathrm{HM}-\mathrm{I}$, i.e. the increasing the number of nitro groups in the molecule could strengthen the explosive performances. 
Table 6. Detonation velocity calculated by using Equation (1) and Equation (2).

\begin{tabular}{ccc}
\hline Name & $D_{1}, \mathrm{~km} / \mathrm{s}$ & $D_{2} \mathrm{~km} / \mathrm{s}$ \\
\hline HM-I & 7.14 & 7.53 \\
HM-II & 7.88 & 8.47 \\
HM-III & 8.42 & 9.20 \\
HM-IV & 8.42 & 9.20 \\
HM-V & 7.88 & 8.47 \\
HM-VI & 7.88 & 8.47 \\
\hline
\end{tabular}

\subsection{Detonation Pressure}

We mention the detonation pressure as the other performance of the hazardous material to establish their ability to do the work and determine whether the explosive material is of high or low brisance.

Generally, the detonation velocity and detonation pressure are calculated by using Kamlet-Jacobs equation [18]:

$$
\begin{gathered}
D(m / s)=1.01 \times\left(N M^{1 / 2} Q^{1 / 2}\right)^{1 / 2}(1+1.30 \rho) \\
P(k b a r)=15.58 \rho^{2} N M^{1 / 2} Q^{1 / 2}
\end{gathered}
$$

where $\rho$ is density of a compound $\left(\mathrm{g} / \mathrm{cm}^{3}\right), N$ is moles of gaseous detonation products, $M$ is average molecular weight of gaseous products $(\mathrm{g} / \mathrm{mol})$, and $Q$ is chemical energy of detonation (cal/g).

At present time we have no necessary data to evaluate detonation velocity by Kamlet-Jacobs Equation, but combining that, the following equations to calculate detonation pressure is

$$
P(k b a r)=15.58\left(D \rho /(1.01(1+1.30 \rho))^{2}\right)
$$

The detonation pressure obtained by Equation (7) is presented in Table 7.

It is necessary to mention the detonation pressure of TNT that is equal to 213 - $259 \mathrm{kbar}$ and is used as a standard. So, the detonation pressure of the HM-I molecule is lower than that of TNT even then $10 \%-20 \%$ deviation of the detonation velocity is accounted [19]. Referring to the results obtained, we could name the materials as high brisance (exception is HM-I) and rank them following: HM-I < TNT < HM-II < HM-V < HM-VI < HM-IV < HM-III. Moreover, the ability to do the work of the molecules consist of the two additional nitro groups is larger than that consisting only one or none of the above $-\mathrm{NO}_{2}$ groups. Hence, the results obtained lead to the conclusion that the ability to do the work of the molecules under investigation depends on the number of the additional nitro groups.

\subsection{Oxygen Balance}

Oxygen balance is used to indicate the degree to which an explosive can be oxidized. The sensitivity, strength, and brisance of hazardous materials are all somewhat dependent upon oxygen balance and tend to approach their maxima as oxygen balance approaches zero. 
Referring to results presented in Table 8, we can conclude that the molecules under investigation contain less oxygen than needed and foresee that the combustion would be incomplete, and large amounts of toxic gases would be present. However, the negative oxygen balance could be used to indicate the shock sensitivity. It is expected that hazardous materials with the oxygen balance closer to zero will be more sensitive to a shock. Hence, the analysis of the oxygen balance indicates HM-I as less sensitive while HM-III or HM-IV as high sensitive. The results of the analysis indicate the relative sensitivity sequence of these molecules: HM-I > HM-III = HM-IV > HM-II = HM-V = HM-VI, i.e. the additional nitro groups could increase sensitivity of the materials.

\section{Conclusions}

We modeled N-(2,4,6-trinitrophenyl)-1H-1,2,4-triazol-3-amine molecule and performed theoretical investigations of it aiming to clear the influence of the nitro group and its position to both the stability, optical and hazardous properties. Referring to the results, we obtained:

- The thermal stability of the HM-IV and HM-V materials is the highest among materials investigated. The chemical stability of these materials is also the highest;

- The HM-IV material requires the smallest amount of energy to induce explosion;

- The HM-III and HM-IV materials could be named as the high brisance materials;

- The materials are not sensitive.

Table 7. Detonation pressure calculated by using Equation (7).

\begin{tabular}{ccc}
\hline Name & Pressure, when $D=D_{1}$, kbar & Pressure, when $D=D_{2}$, kbar \\
\hline HM-I & 231.67 & 257.84 \\
HM-II & 291.33 & 336.61 \\
HM-III & 364.53 & 435.34 \\
HM-IV & 343.60 & 410.34 \\
HM-V & 294.22 & 339.93 \\
HM-VI & 310.73 & 359.01 \\
\hline
\end{tabular}

Table 8. Oxygen balance values.

\begin{tabular}{cc}
\hline Name & Oxygen balance, \% \\
\hline HM-I & -67.76 \\
HM-II & -47.04 \\
HM-III & -31.16 \\
HM-IV & -31.16 \\
HM-V & -47.04 \\
HM-VI & -47.04 \\
\hline
\end{tabular}




\section{Acknowledgements}

This work was conducted within the framework of the LMA scientific project "A theoretical and experimental investigations of new potentially explosive materials using quantum mechanical methods (NSPROG-I4)". The authors would like to thank V. Patasiene for her assistance and fruitful discussions. The authors are thankful for the high performance computing resources provided by the Information Technology Open Access Center of Vilnius University.

\section{References}

[1] Wilson, W.S. (1994) 1-(2',4',6'-Trinitrophenyl)imidazoles and -1,2,4-Triazoles as Energetic Materials. NAWCWPNS Technical Publication 8188, Published by Technical Information Department, Naval Air; Warfare Center Weapons Division, China Lake.

[2] Agrawal, J.P. (2012) Past, Present \& Future of Thermally Stable Explosives. Central European Journal of Energetic Materials, 9, 273-290.

[3] Agrawal, J.P. and Hodgson, R.D. (2007) Organic Chemistry of Explosives. John Wiley \& Sons, Chichester.

[4] Agrawal, J.P. (2010) High Energy Materials. Propellants, Explosives and Pyrotechnics. Wiley-VCH Vergal GmbH\&Co. KGaA, Weinheim. https://doi.org/10.1002/9783527628803

[5] Ayres, J.N., Montesi, L.J. and Bauer R.J. (1973) Small Scale Gap Test (SSGT) Data Compilation: 1959-1972. Vol. 1. Unclassified Explosives. Technical Report (NOLTR) No. 73-132, Naval Ordnance Laboratory, Naval Ordnance Lab., White Oak.

[6] Gibbs, T.R. and Popolato, A. (1980) LASL Explosive Property. Data University of California Press, Los Angeles.

[7] Zeman, S. (1993) The Thermoanalytical Study of Some Aminoderivatives of 1,3,5Trinitrobenzene. Thermochimica Acta, 216, 157-168. https://doi.org/10.1016/0040-6031(93)80389-R

[8] Bapat, V.K., Surve, R.N. and Agrawal, J. P. (1998) Synthesis, Characterization and Evaluationof Explosive Properties of 5-Picrylamino-1,2,3,4-Tetrazole. Proceedings of 2 nd High Energy Materials Conference \& Exhibits, IIT, Madras, 8-10 December 1998, 403-405.

[9] Makashir, P.S., Bapat, V.K., Mahajan, R.R., Mehilal and Agrawal, J.P. (2000) A Comparative Study of Thermal \& Explosive Behaviour of 5-Picrylamino-1,2,3,4Tetrazole (PAT) and 5,5'-Styphnylamino-1,2,3,4-Tetrazole (SAT). Proceedings of International Workshop on Unsteady Combustion \& Interior Ballistics, St. Petersburg, 1, 199-205.

[10] Mehilal, Sikder, N., Sikder, A. K. and Agrawal, J.P. (2004) N,N'-Bis(1,2,4-triazol3-yl)-4,4'-diamino-2,2',3,3',5,5'6,6'-Octanitroazo-Benzene (BTDAONAB): A New Thermally Stable Insensitive High Explosive. Indian Journal of Engineering and Materials Sciences, 11, 516-520.

[11] Becke, A.D. (1993) Density-Functional Thermochemistry. III. The Role of Exact Exchange. The Journal of Chemical Physics, 98, 5648-5652. https://doi.org/10.1063/1.464913

[12] Zhao, Y., Pu, J., Lyncha, B.J. and Truhlara, D.G. (2004) Tests of Second-Generation and Third-Generation Density Functionals for Thermochemical Kinetics. Physical Chemistry Chemical Physics, 6, 673-676. https://doi.org/10.1039/b316260e

[13] Kendall, R.A., Dunning Jr., T.H. and Harrison, R.J. (1992) Electron Affinities of the 
First-Row Atoms Revisited. Systematic Basis Sets and Wave Functions. The Journal of Chemical Physics, 96, 6796-6806. https://doi.org/10.1063/1.462569

[14] Turker, L. (2010) Velocity of Detonation-A Mathematical Model. Acta Chimica Slovenica, 57, 288-296.

[15] Lothrop, W.C. and Handrick, G.R. (1949) The Relationship between Performance and Constitution of Pure Organic Explosive Compounds. Chemical Reviews, 44, 419-445. https://doi.org/10.1021/cr60139a001

[16] Frisch, M.J., Trucks, G.W., Schlegel, H.B., Scuseria, G.E., Robb, M.A., Cheeseman, J.R., Montgomery Jr., J.A., Vreven, T., Kudin, K.N., Burant, J.C., Millam, J.M., Iyengar, S.S., Tomasi, J., Barone, V., Mennucci, B., Cossi, M., Scalmani, G., Rega, N., Petersson, G.A., Nakatsuji, H., Hada, M., Ehara, M., Toyota, K., Fukuda, R., Hasegawa, J., Ishida, M., Nakajima, T., Honda, Y., Kitao, O., Nakai, H., Klene, M., Li, X., Knox, J.E., Hratchian, H.P., Cross, J.B., Bakken, V., Adamo, C., Jaramillo, J., Gomperts, R., Stratmann, R.E., Yazyev, O., Austin, A.J., Cammi, R., Pomelli, C., Ochterski, J.W., Ayala, P.Y., Morokuma, K., Voth, G.A., Salvador, P., Dannenberg, J.J., Zakrzewski, V.G., Dapprich, S., Daniels, A.D., Strain, M.C., Farkas, O., Malick, D.K., Rabuck, A.D., Raghavachari, K., Foresman, J.B., Ortiz, J.V., Cui, Q., Baboul, A.G., Clifford, S., Cioslowski, J., Stefanov, B.B., Liu, G., Liashenko, A., Piskorz, P., Komaromi, I., Martin, R.L., Fox, D.J., Keith, T., Al-Laham, M.A., Peng, C.Y., Nanayakkara, A., Challacombe, M., Gill, P.M.W., Johnson, B., Chen, W., Wong, M.W., Gonzalez, C. and Pople, J.A. (2004) Gaussian 03, Revision D.02. Gaussian, Inc., Wallingford.

[17] Turker, L., Atalar, T., Gumus, S. and Camur, Y. (2009) A DFT Study of Nitrotriazines. Journal of Hazardous Materials, 167, 440-448. https://doi.org/10.1016/j.jhazmat.2008.12.134

[18] Kamlet, M.J. and Jacobs, S.J. (1968) Chemistry of Detonations. I. Simple Method for Calculating Detonation Properties of CHNO Explosives. The Journal of Chemical Physics, 48, 23-55. https://doi.org/10.1063/1.1667908

[19] Keshavarz, M.H. (2007) Theoretical Prediction of Detonation Pressure of CHNO Energy Materials. Indian Journal of Engineering and Materials Sciences, 14, 77-80. 


\section{Supporting Information}

The total energy of the investigated molecules.

\begin{tabular}{cc}
\hline Name of the molecule under study & Total energy, a.u. \\
\hline HM-I & -1142.399 \\
HM-II & -1346.919 \\
HM-III & -1551.450 \\
HM-IV & -1551.477 \\
HM-V & -1346.959 \\
HM-VI & -1346.932 \\
\hline
\end{tabular}

The coordinates of the optimized geometries of DFT calculations.

\section{HM-I}

\begin{tabular}{|c|c|c|c|}
\hline $\mathrm{C}$ & -0.660228 & -1.868504 & -1.584406 \\
\hline $\mathrm{C}$ & -1.810006 & -1.035629 & -1.479477 \\
\hline $\mathrm{C}$ & -2.706266 & -1.118251 & -2.591856 \\
\hline $\mathrm{C}$ & -2.513631 & -2.004481 & -3.636772 \\
\hline $\mathrm{C}$ & -1.418945 & -2.841502 & -3.626740 \\
\hline $\mathrm{C}$ & -0.483460 & -2.772542 & -2.606506 \\
\hline $\mathrm{N}$ & -2.087468 & -0.236163 & -0.421924 \\
\hline $\mathrm{C}$ & -1.734297 & -0.394933 & 0.909406 \\
\hline $\mathrm{N}$ & -1.305609 & -1.526762 & 1.434587 \\
\hline $\mathrm{N}$ & -1.156704 & -1.182377 & 2.734705 \\
\hline $\mathrm{C}$ & -1.514275 & 0.098537 & 2.922455 \\
\hline $\mathrm{N}$ & -1.891873 & 0.633597 & 1.780181 \\
\hline $\mathrm{N}$ & -3.915684 & -0.289124 & -2.683141 \\
\hline $\mathrm{O}$ & -4.024043 & 0.677719 & -1.923843 \\
\hline $\mathrm{N}$ & -1.221839 & -3.792310 & -4.727600 \\
\hline $\mathrm{O}$ & -2.050674 & -3.794098 & -5.624439 \\
\hline $\mathrm{N}$ & 0.506648 & -1.707101 & -0.692333 \\
\hline $\mathrm{O}$ & 0.787574 & -0.569563 & -0.353656 \\
\hline $\mathrm{O}$ & -4.752030 & -0.585529 & -3.515164 \\
\hline $\mathrm{O}$ & 1.143054 & -2.706608 & -0.413938 \\
\hline $\mathrm{O}$ & -0.241842 & -4.519372 & -4.670320 \\
\hline $\mathrm{H}$ & -2.810077 & 0.454438 & -0.598830 \\
\hline $\mathrm{H}$ & -1.487335 & 0.591153 & 3.879435 \\
\hline $\mathrm{H}$ & -0.803197 & -1.855125 & 3.393664 \\
\hline $\mathrm{H}$ & -3.229500 & -2.045449 & -4.441147 \\
\hline $\mathrm{H}$ & 0.397656 & -3.393993 & -2.626362 \\
\hline
\end{tabular}


HM-II

\begin{tabular}{|c|c|c|c|}
\hline $\mathrm{C}$ & -0.563491 & -1.100138 & -0.444656 \\
\hline $\mathrm{C}$ & -0.028302 & 0.176605 & -0.237169 \\
\hline $\mathrm{C}$ & -0.937279 & 1.174352 & 0.150438 \\
\hline $\mathrm{C}$ & -2.287696 & 0.918029 & 0.296511 \\
\hline $\mathrm{C}$ & -2.744909 & -0.373556 & 0.115551 \\
\hline $\mathrm{C}$ & -1.894382 & -1.403690 & -0.238500 \\
\hline $\mathrm{N}$ & 1.356672 & 0.371368 & -0.384213 \\
\hline $\mathrm{C}$ & 2.276159 & -0.269653 & 0.459472 \\
\hline $\mathrm{N}$ & 2.063857 & -0.323272 & 1.763634 \\
\hline $\mathrm{N}$ & 3.102780 & -1.072166 & 2.173592 \\
\hline $\mathrm{C}$ & 3.881320 & -1.412350 & 1.125889 \\
\hline $\mathrm{N}$ & 3.372938 & -0.928257 & 0.015542 \\
\hline $\mathrm{N}$ & -0.506267 & 2.560372 & 0.467832 \\
\hline $\mathrm{O}$ & -1.325515 & 3.439766 & 0.282034 \\
\hline $\mathrm{N}$ & -4.183059 & -0.663399 & 0.309989 \\
\hline $\mathrm{O}$ & -4.900896 & 0.268530 & 0.626766 \\
\hline $\mathrm{N}$ & 0.294227 & -2.207183 & -0.932716 \\
\hline $\mathrm{O}$ & 0.913632 & -2.015014 & -1.958653 \\
\hline $\mathrm{O}$ & 0.612411 & 2.712632 & 0.923467 \\
\hline $\mathrm{O}$ & 0.273047 & -3.235418 & -0.277076 \\
\hline $\mathrm{O}$ & -4.544128 & -1.815454 & 0.140401 \\
\hline $\mathrm{H}$ & 4.777264 & -2.003035 & 1.215287 \\
\hline $\mathrm{H}$ & 3.205384 & -1.296977 & 3.149287 \\
\hline $\mathrm{H}$ & -2.964729 & 1.711298 & 0.568959 \\
\hline $\mathrm{H}$ & -2.265431 & -2.407542 & -0.372907 \\
\hline $\mathrm{N}$ & 1.814925 & 1.420900 & -1.239732 \\
\hline $\mathrm{O}$ & 2.980044 & 1.704409 & -1.159218 \\
\hline $\mathrm{O}$ & 0.969717 & 1.894313 & -1.970640 \\
\hline
\end{tabular}

\section{HM-III}

\begin{tabular}{llll}
\hline $\mathrm{C}$ & -0.485038 & -1.361103 & -1.748462 \\
$\mathrm{C}$ & -1.772693 & -0.885503 & -1.479929 \\
$\mathrm{C}$ & -2.808073 & -1.396417 & -2.277197 \\
$\mathrm{C}$ & -2.567878 & -2.305134 & -3.290949 \\
$\mathrm{C}$ & -1.278048 & -2.762298 & -3.482818 \\
$\mathrm{C}$ & -0.222861 & -2.317239 & -2.710431 \\
$\mathrm{~N}$ & -1.961073 & 0.030315 & -0.422707 \\
$\mathrm{C}$ & -1.810534 & -0.364043 & 0.907273 \\
\hline
\end{tabular}




\section{Continued}

\begin{tabular}{|c|c|c|c|}
\hline $\mathrm{N}$ & -2.145770 & -1.582434 & 1.281851 \\
\hline $\mathrm{N}$ & -1.762166 & -1.569136 & 2.566803 \\
\hline $\mathrm{C}$ & -1.232687 & -0.360929 & 2.917312 \\
\hline $\mathrm{N}$ & -1.241116 & 0.418864 & 1.871158 \\
\hline $\mathrm{N}$ & -4.230589 & -1.015435 & -2.070135 \\
\hline $\mathrm{O}$ & -4.963649 & -1.112340 & -3.034862 \\
\hline $\mathrm{N}$ & -1.018709 & -3.761820 & -4.546453 \\
\hline $\mathrm{O}$ & -1.975257 & -4.137527 & -5.199348 \\
\hline $\mathrm{N}$ & 0.685909 & -0.839899 & -1.001586 \\
\hline $\mathrm{O}$ & 0.809599 & 0.366461 & -0.930756 \\
\hline $\mathrm{O}$ & -4.565786 & -0.665482 & -0.952924 \\
\hline $\mathrm{O}$ & 1.447324 & -1.675719 & -0.545843 \\
\hline $\mathrm{O}$ & 0.133401 & -4.132433 & -4.686951 \\
\hline $\mathrm{H}$ & -0.869868 & -0.139350 & 3.904897 \\
\hline $\mathrm{H}$ & -3.378836 & -2.661397 & -3.905310 \\
\hline $\mathrm{H}$ & 0.776652 & -2.690983 & -2.867721 \\
\hline $\mathrm{N}$ & -2.589283 & 1.287803 & -0.721442 \\
\hline $\mathrm{O}$ & -2.961638 & 1.936033 & 0.217337 \\
\hline $\mathrm{O}$ & -2.653239 & 1.551234 & -1.902181 \\
\hline $\mathrm{N}$ & -1.894121 & -2.747336 & 3.408792 \\
\hline $\mathrm{O}$ & -1.538294 & -2.567591 & 4.547791 \\
\hline $\mathrm{O}$ & -2.330414 & -3.723974 & 2.875850 \\
\hline
\end{tabular}

\section{HM-IV}

\begin{tabular}{llll}
\hline $\mathrm{C}$ & -0.570186 & -1.378523 & -1.698125 \\
$\mathrm{C}$ & -1.858197 & -0.858995 & -1.533211 \\
$\mathrm{C}$ & -2.843991 & -1.343893 & -2.406727 \\
$\mathrm{C}$ & -2.554352 & -2.267711 & -3.393334 \\
$\mathrm{C}$ & -1.269386 & -2.769570 & -3.479494 \\
$\mathrm{C}$ & -0.264002 & -2.352145 & -2.628896 \\
$\mathrm{~N}$ & -2.094986 & 0.071474 & -0.500856 \\
$\mathrm{C}$ & -2.031545 & -0.303444 & 0.843123 \\
$\mathrm{~N}$ & -2.520753 & -1.473746 & 1.244360 \\
$\mathrm{~N}$ & -2.199847 & -1.480617 & 2.541943 \\
$\mathrm{C}$ & -1.568478 & -0.334919 & 2.848900 \\
$\mathrm{~N}$ & -1.424448 & 0.431742 & 1.803667 \\
$\mathrm{~N}$ & -4.266058 & -0.921665 & -2.310366 \\
$\mathrm{O}$ & -4.919014 & -0.976579 & -3.333937 \\
\hline
\end{tabular}




\section{Continued}

\begin{tabular}{llll}
\hline $\mathrm{N}$ & -0.961444 & -3.788063 & -4.511231 \\
$\mathrm{O}$ & -1.874927 & -4.135456 & -5.237541 \\
$\mathrm{~N}$ & 0.553258 & -0.882956 & -0.866028 \\
$\mathrm{O}$ & 0.742598 & 0.316015 & -0.847540 \\
$\mathrm{O}$ & -4.681832 & -0.585788 & -1.215905 \\
$\mathrm{O}$ & 1.212620 & -1.733679 & -0.293067 \\
$\mathrm{O}$ & 0.183544 & -4.202496 & -4.554013 \\
$\mathrm{H}$ & -3.325312 & -2.602840 & -4.068170 \\
$\mathrm{H}$ & 0.732389 & -2.758442 & -2.705299 \\
$\mathrm{~N}$ & -2.689827 & 1.335506 & -0.843361 \\
$\mathrm{O}$ & -3.094725 & 1.997201 & 0.072601 \\
$\mathrm{O}$ & -2.692834 & 1.589966 & -2.027186 \\
$\mathrm{H}$ & -2.426752 & -2.251295 & 3.151900 \\
$\mathrm{~N}$ & -1.119312 & -0.070805 & 4.209929 \\
$\mathrm{O}$ & -0.573665 & 0.983806 & 4.432210 \\
$\mathrm{O}$ & -1.348838 & -0.973428 & 5.008398 \\
\hline
\end{tabular}

\section{HM-V}

\begin{tabular}{llll}
\hline $\mathrm{C}$ & -0.662287 & -1.862500 & -1.591187 \\
$\mathrm{C}$ & -1.815058 & -1.039886 & -1.483546 \\
$\mathrm{C}$ & -2.729956 & -1.148202 & -2.574108 \\
$\mathrm{C}$ & -2.543996 & -2.041134 & -3.614408 \\
$\mathrm{C}$ & -1.436960 & -2.861952 & -3.613676 \\
$\mathrm{C}$ & -0.489244 & -2.775457 & -2.608464 \\
$\mathrm{~N}$ & -2.081865 & -0.212859 & -0.435730 \\
$\mathrm{C}$ & -1.732861 & -0.356597 & 0.891660 \\
$\mathrm{~N}$ & -1.298219 & -1.488857 & 1.435383 \\
$\mathrm{~N}$ & -1.145717 & -1.141950 & 2.723833 \\
$\mathrm{C}$ & -1.509091 & 0.136519 & 2.882436 \\
$\mathrm{~N}$ & -1.889929 & 0.676457 & 1.753866 \\
$\mathrm{~N}$ & -3.954069 & -0.333773 & -2.651713 \\
$\mathrm{O}$ & -4.047263 & -0.655455 & -1.920816 \\
$\mathrm{~N}$ & -1.243930 & -3.821894 & -4.711691 \\
$\mathrm{O}$ & -2.086173 & -3.839347 & -5.594438 \\
$\mathrm{~N}$ & 0.508098 & -1.692954 & -0.703964 \\
$\mathrm{O}$ & 0.775169 & -0.555014 & -0.354056 \\
$\mathrm{O}$ & -4.810607 & & -667212 \\
\hline
\end{tabular}




\section{Continued}

\begin{tabular}{llll}
\hline $\mathrm{O}$ & 1.155685 & -2.687163 & -0.435907 \\
$\mathrm{O}$ & -0.254767 & -4.535070 & -4.661049 \\
$\mathrm{H}$ & -3.272444 & -2.100570 & -4.406443 \\
$\mathrm{H}$ & 0.396398 & -3.390423 & -2.633278 \\
$\mathrm{H}$ & -2.801806 & 0.478512 & -0.625382 \\
$\mathrm{H}$ & -0.795485 & -1.783923 & 3.417703 \\
$\mathrm{~N}$ & -1.462404 & 0.772144 & 4.189896 \\
$\mathrm{O}$ & -1.824592 & 1.923414 & 4.273448 \\
$\mathrm{O}$ & -1.051106 & 0.057105 & 5.098075 \\
\hline
\end{tabular}

\section{HM-VI}

\begin{tabular}{|c|c|c|c|}
\hline $\mathrm{C}$ & -0.665744 & -1.882579 & -1.584754 \\
\hline $\mathrm{C}$ & -1.809013 & -1.048596 & -1.478863 \\
\hline $\mathrm{C}$ & -2.719101 & -1.136448 & -2.573369 \\
\hline $\mathrm{C}$ & -2.539166 & -2.023808 & -3.619730 \\
\hline $\mathrm{C}$ & -1.441960 & -2.857574 & -3.618321 \\
\hline $\mathrm{C}$ & -0.498195 & -2.790288 & -2.607896 \\
\hline $\mathrm{N}$ & -2.068836 & -0.225422 & -0.423301 \\
\hline $\mathrm{C}$ & -1.757707 & -0.407240 & 0.905512 \\
\hline $\mathrm{N}$ & -1.335324 & -1.537152 & 1.430048 \\
\hline $\mathrm{N}$ & -1.227562 & -1.192729 & 2.729874 \\
\hline $\mathrm{C}$ & -1.603211 & 0.099827 & 2.933800 \\
\hline $\mathrm{N}$ & -1.949421 & 0.623182 & 1.789088 \\
\hline $\mathrm{N}$ & -3.931905 & -0.304959 & -2.650230 \\
\hline $\mathrm{O}$ & -4.008372 & 0.687842 & -1.922596 \\
\hline $\mathrm{N}$ & -1.254321 & -3.811379 & -4.723598 \\
\hline $\mathrm{O}$ & -2.092448 & -3.811767 & -5.610426 \\
\hline $\mathrm{N}$ & 0.504738 & -1.729477 & -0.691877 \\
\hline $\mathrm{O}$ & 0.775517 & -0.596443 & -0.328470 \\
\hline $\mathrm{O}$ & -4.794865 & -0.628860 & -3.441544 \\
\hline $\mathrm{O}$ & 1.148613 & -2.728672 & -0.439307 \\
\hline $\mathrm{O}$ & -0.273573 & -4.535633 & -4.674037 \\
\hline $\mathrm{H}$ & -3.263849 & -2.069040 & -4.416118 \\
\hline $\mathrm{H}$ & 0.380088 & -3.415783 & -2.632277 \\
\hline $\mathrm{H}$ & -2.767546 & 0.487346 & -0.611108 \\
\hline $\mathrm{N}$ & -0.756860 & -2.128595 & 3.723190 \\
\hline $\mathrm{H}$ & -1.598777 & 0.568692 & 3.901211 \\
\hline $\mathrm{O}$ & -0.476136 & -3.221116 & 3.324546 \\
\hline $\mathrm{O}$ & -0.715579 & -1.671029 & 4.842295 \\
\hline
\end{tabular}


Submit or recommend next manuscript to SCIRP and we will provide best service for you:

Accepting pre-submission inquiries through Email, Facebook, LinkedIn, Twitter, etc. A wide selection of journals (inclusive of 9 subjects, more than 200 journals)

Providing 24-hour high-quality service

User-friendly online submission system

Fair and swift peer-review system

Efficient typesetting and proofreading procedure

Display of the result of downloads and visits, as well as the number of cited articles Maximum dissemination of your research work

Submit your manuscript at: http://papersubmission.scirp.org/

Or contact ajac@scirp.org 